\title{
Prostitute's Adolescent Clients' Understanding of Local Wisdom on Social Relations
}

\author{
R. Humsona, M. Wijaya, J. Leibo \\ Department of Sociology, Faculty of Social and \\ Political Sciences \\ Universitas Sebelas Maret \\ Surakarta, INDONESIA
}

\author{
S. Yuliani \\ Public Administration Science, Faculty of Social and \\ Political Sciences \\ Universitas Sebelas Maret \\ Surakarta, INDONESIA
}

adolescent clients' shows that there has been a deviation from the local wisdom value and norm, particularly social relation [5]. For that reason, this study is important to study the characteristics of prostitute's client-adolescents. The result of research can be utilized to develop an internalization model of local wisdom value to reduce adolescents' interest in establishing a sexual relation.

\section{LITERATURE REVIEW}

\section{a) Concept of Adolescence}

Adolescence derives from the word adolescere meaning growing, growing to be an adult. Meanwhile, the definition of adolescence is an age when individual integrates with adult society, the age when the child no longer falls below the level of older people, but at the equal one at least in the term of right [6].

World Health Organization (WHO, 1974) provided a more conceptual definition with three criteria: physical, social-psychological, and economic. Physically, individual has been developed for the first time he/she shows his/her secondary sexual signs until the time when he/she achieves sexual maturity. Social-psychologically he/she experiences mental development and identification pattern from childhood to adulthood. The adolescent's identification pattern will be affected by membership group, the group in which adolescents become their members [9] [7]. It is noteworthy that recently group not only utilizes physical meeting, but also social media. Thus, social media also affect identification pattern, value and norm on which the adolescents hold. And economically the adolescents experience development process from dependency to more independence.

\section{b) Prostitute's Adolescent Client}

The prostitute's client is anyone establishing sexual relationships with rewarding. The adolescent becoming prostitute's client is affected by its membership group. It is because, the group to which adolescent belongs becomes the main reference source for the adolescent of the term of perception and attitude related to lifestyle [3]. Membership group also becomes the learning source of using internet firstly for them, either to be able to undertake certain internet activity or for fun, for example visiting pornographic sites [14].

Brown (2005) mentioned that, the men with thicker pocket more frequently come to clubs and buys high-class call-girl, while those with thinner pocket tends to subscribe to the inexpensive brothel sector. Considering that adolescents still have economic dependency, the location they come to be dependent on the amount of money they have. 


\section{c) Prostitute's adolescent client and Local Wisdom, Values}

Local wisdom is defined by Naritoom (2010) as knowledge accumulated from life experiences, learnt from various situations surrounding human life in an area. Local wisdom is knowledge developed from ancestors in dealing with life environment around them, making the knowledge a part of culture and introducing as well as forwarding it from one generation to another. Such the traditional knowledge forms arise through stories, legends, songs, rituals, and local rule or law [1]. Citing Naritoom (2010), Anamofa agrees that local wisdom is an identity issue. As a local knowledge system, it distinguishes a local community from another. Such the difference can be seen from local wisdom types that can be traced back from: local wisdom in relation to food, medication, production system, housing, clothing, and social relations between fellow human beings.

For Indonesian people, local wisdom is a product (idea, practice and work) of its stakeholder's culture concerning the environment and human being based on divinity, humanity and environment integrated in such a way that ensures harmony between human being and nature surrounding [12]. In the context of prostitution-user adolescent, deviating behavior seems to occur. Such deviation can be affected by membership group to which adolescents belong. Prostitute's adolescent clients deviate from social relation values. It's because in prostitution, men become users more than women, so that what is relevant to discuss here is social relation value about how the men should develop his relationship with women. For many examples suggested by Lestari (2013), the local values relevant here concerns self-guidelines, remembering God, noble character tenet, alertness, independence.

\section{METHOD}

The research was taken place in Surakarta City. This study employed a qualitative method with phenomenological strategy. The data were collected directly from its source (9 prostitutions adolescence client), using in-depth interview technique. To validate the data, source triangulation [11] was used, through female commercial sex workers. The data analysis was conducted using an interactive model with three components: data reduction, data display, conclusion drawing (Miles and Huberman, 1992). Analysis was also conducted along with the informants involved in data collection.

\section{RESUlt AND Discussion}

\section{a) Prostitution Location in Surakarta City}

In Surakarta called tourist city, there are some proliferating prostitution locations. If categorized by place, it can be called: opened, semi-opened, and closed. The opened location is on the street edge, semi-opened in café, beauty salon, massage house, telecommunication stall, mall (shopping center). Meanwhile, the closed location is in hotel and brothel.

Some prostitution locations developed after the closing of Silir localization. In the place formerly known as 'clean' from prostitution, new network grows continuously with new devotees, new terms and vehicle and media. Procurers, pimps, and new users come with various backgrounds.
Some years ago, procurers were generally those aged above 30 years, but now some of them are teens [2]. Women usually still serve as sex commercial workers. The clients (users) formerly largely adults, now have younger age, even some of them are still in Junior High Schools. Junior High School users also know prostitution from their schoolmates or peers.

Hidangan istimewa Kampung (HIK = special kampong meal) stall, or called angkringan, is one of locations proliferating in the street edge. HIK formerly identical with man's world now provides escort girls. They usually bring the girls to the closest inn. The one of informant said:

"I could meet with female prostituted in HIK around RRI (Radio Republic Indonesia). I do sexual intercourse in the inns around there."

Another new location is an illegal motor racing arena in highway starting when the public traffic begins to be quiet. The racers bet on a certain amount of money agreed. The winner of the race will be rewarded with a night with a young girl on whom their bet. As soon as he is stated as the winner, the racer will immediately go bringing the girl with him to the hotel. The young girl will reward with betted money. Several bets can occur with different groups overnight.

\section{b) The Characteristics of Prostitute's Adolescent clients}

Prostitute's clients now tend to be younger. This study found that the users have made sexual relation commercially since they were 15 years old. However, some informant stated that actually some elementary school children have known prostitution. Their status is generally student and college students. They come from inside or outside Surakarta City. Viewed from marriage status, they are all not married. They stated confidently that they will cease their habit after they have gotten married later.

Viewed from social class, it can be found that users come from lower to upper classes. The lower-class users come to prostitution in opened location, for example, in RRI (Republic of Indonesia's Radio) area, around Tirtonadi Bus Terminal, or former Bale Kambang tourist location. Here the location is opened enough, so that everyone may enter into easily. Meanwhile the middleupper class user may follow motor racing, utilizing pimp or procurer, and some of them use social media.

\section{c) The Prostitute's Adolescent Clients' Conception} on Local Wisdom Value

From this research, it can be found that all of users agree that making sexual relation out of marriage is prohibited. They got this value from family and school. Family always implants kindness value and norm to be obeyed by its members. Without regarding child age, family, particularly parents, has explained about sexual relation that may be developed by an individual who has gotten married.

However, when growing adolescent, membership group also affects (Merton, 1965). In addition to family and school, further knowledge is acquired from the social environment like playmates either inside or outside school. For adolescents, interaction with the social environment, this social environment is very important, 
even is considered as more important from family. Moreover, when knowledge and advice given without concrete examples from parents and teachers or parents' or teachers' practice in contradiction with their advice. Therefore, the value and norm implanted in family or school can be replaced by the group value. If the group has freedom value in sexual relation, this permissive value can encourage adolescent to establish sexual relations in prostitution to get group recognition. In addition, the fun obtained from sexual relation makes adolescents ignore noble character, decency tenets, and even try to forget God.

\section{CONCLUSION}

Adolescence is the age vulnerable to negative effect. The membership group to which the adolescent belongs can be an important factor. The desire to be accepted in a group and experience of getting fun, can make adolescents ignore local wisdom value the formerly understand. The result of current research recommends the local wisdom, values to be explored and redistributed in social relation, particularly among adolescents.

\section{REFERENCES}

[1] Anamofa, Jusuf Nikholas. 2011. Kearifan Lokal Guna Pemecahan Masalah. http://edukasi.kompasiana. com/2011/05/28/kearifan lokal /

[2] Brown, Louise. 2005. Sex Slaves, Sindikat Perdagangan Perempuan di Asia. Yayasan Obor Indonesia. Jakarta.

[3] Conger, JJ. 1991. Adolescence and youth (4th ed). New York: Harper Collins.

[4] Humsona, Rahesli. 2010. Trafficking: Jaringan Prostitusi Anak di Kota Surakarta.

[5] Humsona, Rahesli. et al. 2015. Mengurangi Penggunaan Anakanak dalam Prostitusi melalui Internalisasi Nilai-nilai Relasi Sosial bagi Pengguna (Studi di Kota Surakarta).

[6] Hurlock, EB. 1999. Psikologi Perkembangan: Suatu Pendekatan Sepanjang Ruang Kehidupan. Jakarta: Erlangga.

[7] Johnson, Doyle Paul. 1981. Teori Sosiologi Klasik dan Modern. Jakarta: PT Gramedia

[8] Lestari, Sri. 2013. Nilai Kearifan Lokal di Lokalisasi Sunan Kuning. Semarang: Universitas Negeri Semarang.

[9] Merton, Robert K. 1965. Social Theory and Social Structure. Revised and Enlarged Edition. New York: The Free Press.

[10] Miles, Matthew B \& A Michael Huberman. 1992. Analisis Data Kualitatif. UI Press. Jakarta.

[11] Moleong. Lexy J. 1995. Metode Penelitian Kualitatif. Bandung: Remaja Rosdakarya.

[12] Mungmachon, Miss Roikhwanphut. 2012. Knowledge and Lokal Wisdom: Community Treasure. http://www. ijhssnet.com/journals/Vol_2_No_13 July_2012/18.pdf

[13] Naritoom, Chatcharee. 2010 Local Wisdom/Indigenous Knowledge System. Nakhon Pathom, Thailand: Kasetsart University.

http://unisdrapps.net/confluence/download/attachments/3440652/ UNISDR-Informs-4.pdf

[14] Qomariyah, Astutik Nur. 2009. Perilaku Penggunaan Internet pada Kalangan Remaja di Perkotaan. Surabaya: Universitas Airlangga. 